\title{
Specific interventions for prevention of muscle injury in lower limbs: systematic review and meta-analysis
}

\author{
Intervenções específicas para prevenção de lesão muscular \\ em membros inferiores: revisão sistemática e meta-análise
} Intervenciones específicas para la prevención de lesiones musculares
en miembros inferiores: revisión sistemática y meta-análisis

\section{Jaqueline Santos Silva Lopes $\circledast^{[a, b]}$, Aryane Flauzino Machado®[c], Allysiê Priscila Cavina $\circledast^{[d]}$, Jéssica Kirsch Michelletti ${ }^{[\mathrm{d}]}$, Aline Castilho de Almeida ${ }^{[e]}$, Carlos Marcelo Pastre ${ }^{[\mathrm{d}]^{*}}$}

\footnotetext{
[a] Centro Universitário do Vale do Araguaia (Univar), Barra do Garças, MT, Brazil

${ }^{[b]}$ Universidade Federal de Mato Grosso (UFMT), Cuiabá, MT, Brazil

[c] Faculdade Dom Bosco, Cornélio Procópio, PR, Brazil

[d] Universidade Estadual Paulista "Júlio de Mesquita Filho" (Unesp), Presidente Prudente, SP, Brazil

[e] Universidade Federal de São Carlos (UFSCar), São Carlos, SP, Brazil
}

\section{Abstract}

Introduction: Muscle injuries show an incidence associated with extreme stretching, or even a highintensity eccentric contraction. Such injuries cause severe damage to athletes, including lower performance, withdrawal, and psychological distress. In this scenario, the study of effective preventive methods is an indispensable factor in the routine of professional athletes, to reduce the incidence of injuries. Objective: To verify the effectiveness of three different interventions (warm-up, neuromuscular training, and eccentric

\footnotetext{
* JSSL: Doctoral student, e-mail: jaqueee-santosss@hotmail.com AFM: PhD, e-mail: ary_machado@hotmail.com APC: Master's student, e-mail: lysi_cavina@hotmail.com JKM: Doctoral student, e-mail: jessicamichelleti@hotmail.com ACA: PhD, e-mail: alinecastilho@live.com CMP: PhD, e-mail: pastre@fct.unesp.br
} 
exercise) to prevent muscle injuries in the lower limbs. Method: We searched the Cochrane Library, EMBASE, SPORTDiscus, PEDro, and PubMed databases from the earliest records until January 20, 2018. The search was performed from word combinations such as clinical trial, muscle strain, injury prevention. The data related to the outcome of prevention were grouped in meta-analysis and described in Risk Ratio (RR) with 95\% confidence interval. Results: Sixteen studies were included: five assessed eccentric exercise, three investigated neuromuscular training, and eight observed warm-up. The eccentric exercise (RR $=3.49$, $95 \% \mathrm{CI} 2.36,5.16, \mathrm{p}<0.00001$ ) and the neuromuscular training ( $\mathrm{RR}=2.73,95 \% \mathrm{CI} 2.03,2.68, \mathrm{p}<0.00001$ ) showed significant effects on the prevention of muscle injuries in lower limbs. On the other hand, warm-up $(\mathrm{RR}=1.57,95 \% \mathrm{CI} 0.92,2.7, \mathrm{p}=0.10)$ was irrelevant in reducing the incidence of injuries in the body segment investigated. Conclusion: The outcomes presented provide clinical relevance inherent in the field practices, with intrinsic potential for practical application in the management of specific preventive techniques.

Keywords: Athletic Injuries. Muscle Stretching Exercises. Sports Medicine. Lower Extremity. Physical Therapy Specialty.

\section{Resumo}

Introdução: Lesões musculares apresentam incidência associada à alongamento extremo, ou ainda, a uma contração excêntrica de alta intensidade. Tais lesões, acarretam prejuízos graves aos atletas que incluem queda de rendimento, afastamento e transtornos psicológicos. Neste cenário, o estudo de métodos preventivos eficazes, constituem fator indispensável na rotina de atletas profissionais, a fim de, reduzir a incidência de lesões. Objetivo: Verificar a eficácia de três diferentes intervenções (aquecimento, treinamento neuromuscular e exercício excêntrico) para prevenção de lesões musculares em membros inferiores. Método: Foram pesquisadas as bases de dados Cochrane Library, EMBASE, Sports Discus, PEDro e PubMed desde os registros mais antigos até 20 de janeiro de 2018. A busca foi realizada a partir de combinações de palavras, como, clinical trial, muscle strain, injury prevention. Os dados relacionados ao desfecho prevenção foram agrupados em meta-análise e descritos em Risk Ratio (RR) com intervalo de confiança de 95\%. Resultados: Foram incluídos 16 estudos. Destes, cinco avaliaram o exercício excêntrico, três investigaram o treino neuromuscular e oito observaram o aquecimento. $O$ exercício excêntrico $(R R=3.49 ; 95 \%$ CI 2.36, 5.16; $p<0.00001)$ e o treino neuromuscular ( $R R=2.73 ; 95 \%$ CI 2.03, 2.68; $p<0.00001)$ demonstram efeitos significativos na prevenção de lesões musculares em membros inferiores. Por outro lado, o aquecimento ( $R R=1.57 ; 95 \%$ CI 0.92, 2.7; $p=0.10)$ mostrou-se irrelevante na diminuição da incidência de lesões no segmento corporal investigado. Conclusão: Os desfechos apresentados fornecem relevância clínica inerente as práticas de campo, com potencial intrínseco para aplicação prática no manejo de técnicas preventivas específicas.

Palavras-chave: Lesões Atléticas. Exercícios de Alongamento Muscular. Medicina Esportiva. Extremidade mais baixa. Especialidade em Fisioterapia.

\section{Resumen}

Introducción: Lesiones musculares presentan incidencia asociada al estiramiento extremo, o, a una contracción excéntrica de alta intensidad. Tales lesiones, acarrean graves daños a los atletas que incluyen caída de rendimiento, alejamiento y trastornos psicológicos. En este escenario, el estudio de métodos preventivos eficaces, constituyen un factor indispensable en la rutina de atletas profesionales, a fin de reducir la incidencia de lesiones. Objetivo: Verificar la eficacia de tres diferentes intervenciones (calentamiento, entrenamiento neuromuscular y ejercicio excéntrico) para prevención de lesiones musculares en miembros inferiores. Método: Se ha investigado la base de datos Cochrane Library, EMBASE, Sports Discus, PEDRO y PubMed desde los registros más antiguos hasta el 20 de enero de 2018. La búsqueda se realizó a partir de combinaciones de palabras, como, trial trial, prevención de la prevención. Los datos relacionados con el desenlace de prevención se agruparon en metaanálisis y se describieron em Risk Ratio (RR) con un intervalo 
de confianza del 95\%. Resultados: Se incluyeron 16 estudios. De ellos, cinco evaluaron el ejercicio excéntrico, tres investigaron el entrenamiento neuromuscular y ocho observaron el calentamiento. El ejercicio excéntrico $(R R=3.49,95 \% C I 2.36,5.16, p<0.00001)$ y el entrenamiento neuromuscular $(R R=2.73,95 \% C I 2.03,2.68$, $p<0.00001)$ demuestran efectos significativos en la prevención de lesiones musculares en miembros inferiores. Por otro lado, el calentamiento ( $R R=1.57,95 \%$ CI 0.92, 2.7, $p=0.10$ ) se mostró irrelevante en la disminución de la incidencia de lesiones en el segmento corporal investigado. Conclusión: Los resultados presentados proporcionan relevancia clínica inherente a las prácticas de campo, con potencial intrínseco para aplicación práctica en el manejo de técnicas preventivas específicas.

Palabras clave: Lesões Atléticas. Exercícios de Alongamento Muscular. Medicina Esportiva. Extremidade mais Baixa. Especialidade en Fisioterapia.

\section{Introduction}

Muscle injuries are common in the sport field. Sports such as athletics and soccer have a high incidence of muscle injuries in lower limbs, mainly due to biomechanical (extrinsic) and physiological (intrinsic) reasons that involve, among others, excessive training and inadequate conditioning [1]. In these sports, the injury rate reaches $100 \%$ during a season, being associated with the athlete positioning and specific modality in the field $[1,2]$. Other modalities also have high indexes of this type of injury, such as rugby, basketball, and cricket, which are frequent causes of athletes' absence in training and competitions $[1,2]$.

Biarticular muscles and more complex architectures of muscles are susceptible to muscle strain, such as the hamstrings and long adductor, which together correspond to more than $50 \%$ of injuries in soccer [3-6]. For being fast-contracting, these muscles are more exposed to the mechanism of eccentric contraction. In addition, they have higher muscular pre-tension threshold [7].

Edouard P. et al. [8] described the incidence of athletic injuries in a review study. The results of this review indicate that women represent $19-24 \%$ of thigh muscle injuries; and men, from $27-33 \%$ [9-11].

Previous studies [12-15] with soccer players establish that age and injury history are directly related to the risk of injury in the hamstrings, and these factors are called non-modifiable. However, they argue about the need for greater emphasis on appropriate interventions, which are called modifiable factors, including nutrition, emotional aspects, and proper conditioning, to reduce the risk of injuries in these athletes.

Different interventions are addressed in the literature, in the preventive scope. Among them, we can observe protocols aimed at gaining trainable physical abilities, which include strength, flexibility, balance and proprioception (neuromuscular). In this scenario, muscle training and warm-up present evidence in the literature regarding to modifiable risk factors for the incidence of lower limb muscle injury, resulting from sports practice [16-20].

The literature mentions several benefits derived from eccentric exercise, which include higher levels of strength, balance, performance, and coordination. Regarding the preventive character, Opar et al. [18], for example, included 210 Australian soccer athletes, who performed an eccentric evaluation for hamstrings at the beginning, during and at the end of the season. The study concluded that individuals with less eccentric strength are more exposed to the occurrence of injury in the segment analyzed.

Warm-up, a practice incorporated into sport training, aims to obtain an ideal body state before practice and/or sport training, such as a kinetic and coordinate preparation in the prevention of injuries. In the literature, the search for protocols that include different modifiable factors and exercises to which they refer to the sporting gesture is idealized; however, disagreements about the actual effect of these protocols in practice remain uncertain $[21,22]$.

From the above and considering the damages resulting from musculoskeletal injuries, a systematic review with meta-analysis, addressing the comparison between different preventive strategies for a control group, seems pertinent to clarify and quantify the real 
benefits related to the minor injury index, based on the management of the interventions verified [23]. Moreover, quantitative evidence may be capable of directing clinical practices that are scientifically grounded as to their outcomes.

Therefore, this systematic review with a metaanalysis is aimed at investigating the effectiveness of different interventions (eccentric exercise, neuromuscular training, and warm-up) to prevent muscle injuries in lower limbs and to analyze their real efficacy when compared with a control group in professional athletes.

\section{Methods}

This systematic review was registered in the International Prospective Record of Systematic Reviews (PROSPERO), with registration number CRD42018105763. The guidelines for Preferred Reporting Items for Systematic Reviews and MetaAnalyses (PRISMA) were followed to report items needed for a good quality systematic review and meta-analysis.

\section{Search strategy}

The studies were selected from five databases: Cochrane Library; EMBASE; SPORTDiscus; PEDro; and PubMed from the oldest records until January 20th, 2018 , the date on which all searches were performed. Terms and keywords related to randomized clinical trials, muscle strain injuries, and prevention of muscle injury were used. A manual search was performed on the reference list of eligible studies to complement the electronic searches.

There was no restriction regarding the sample condition (age, sex or level of physical activity), date of publication or language of the studies.

\section{Selection of studies}

The studies selected compared preventive strategies of muscle injury with the conventional trainings of the sport modality practiced. To be included, studies should meet the following criteria: 1) a randomized clinical trial or cohort study comparing at least one of the following preventive interventions in isolation (eccentric exercise, neuromuscular training, and warm-up) with a control group, characterized by only usual trainings; and 2) to report incidence/number of muscle injuries in the lower limbs. Articles that did not meet all the inclusion criteria mentioned were excluded.

Regarding the initial number of articles found in the databases searched, Pubmed had 4,438 works, 132 in SportDiscus, 711 in Cochrane, 685 in Embase, and 102 in PEDro. The study selection process was performed by two independent researchers (APSC, VCZ) and conducted in stages (duplicates, title, abstract and full text), as represented in the study flowchart (Figure 1). In cases of disagreement, a third researcher (JSSL) was contacted, and disagreements were resolved by consensus.

\section{Data extraction}

Relevant information, including the author/year of publication, characteristics of participants, type of intervention used, number of events observed, sample size and methodological quality assessment were extracted (Table 1). This step was performed by two authors (VCZ, APSC) and again, in case of disagreement, a third researcher was contacted (JSSL). When no data was available, he/she was chosen to impute such data, as suggested by Askling et al. [24].

When more than one muscle group was evaluated by the same study, the data obtained from the muscle group with the weakest effect were chosen, avoiding risks of misinterpretation.

\section{Methodological Quality Assessment}

The methodological quality of the studies was evaluated using the PEDro Scale (0-10) by two independent evaluators (VCZ and APSC) and was not considered an inclusion criteria. Each study was evaluated for eligibility criteria, random allocation, secret allocation, baseline comparisons, blinding of subjects, therapists and evaluators, follow-up with less than $15 \%$ of loss, adequate treatment according to allocation or intention to treat, intergroup statistical comparisons and measures of precision and variability. The total score ranges from zero to 10 points, in which higher scores represent better methodological quality. A PEDro score equal to or greater than 7 was considered "high quality", studies whose scores were 5 or 6 were considered "moderate quality" and those whose score was 4 or less were considered "poor quality" $[25,26]$. 
An adapted version of the GRADE approach was used for assessment of the overall quality of evidence and strength of recommendation, as suggested by the Cochrane Back Review Group. In summary, the GRADE classification was based on 4 factors: design limitations $[75 \%$ of study participants with high methodological quality (PEDro score 7 points)], inconsistent results (75\% participants from studies with findings in the same direction ), imprecision (300 participants for each group), and publication bias (meta-analyses with more than 10 studies). Overall quality of evidence was defined as high quality (further study is very unlikely to change our confidence in the estimate of effect), moderate quality (further study is likely to have an important impact on our confidence in the estimate of effect and may change the estimate), low quality (further study is very likely to have an important impact on our confidence in the estimate of effect and is likely to change the estimate) and very low quality (any estimate is very uncertain) [25].

Synthesis and analysis of data

All meta-analysis calculations were performed using Review Manager software - RevMan (version 5.3, Copenhagen: The Nordic Cochrane Center, The Cochrane Collaboration, 2014). The analysis of the data grouping was calculated using random and fixed effect models, depending on the heterogeneity of the studies $\left(\mathrm{I}^{2}>50 \%\right.$ random effect). The data were grouped and described as RR (risk ratio) and 95\% of confidence interval $(95 \% \mathrm{CI})$ using the statistical method of M-H (Mantel-Haenszel). The information related to the characteristics of the participants of the studies included were shown in values of mean, minimum, maximum, and standard deviation as presented by the authors of each study.

\section{Results}

Characteristics of the studies included

The searches performed in the databases obtained a total of 5,360 studies after duplicate removal. From these studies, 5,168 were excluded by title, while 138 were excluded by abstract (Figure 1). Thus, 54 studies were considered eligible for full-text reading, after the exclusions by titles and abstracts. From these studies, 38 studies were excluded for not presenting full text, having insufficient data and not assessing the primary outcome. In the end, 16 studies met the inclusion criteria proposed. Figure 1 shows the flowchart described above.which

The studies included are randomized controlled trials and cohort studies, published between 2000 [27] and 2017 [28]. They comprised a total of 10,714 participants, men (75.6\%) and women (24.4\%).

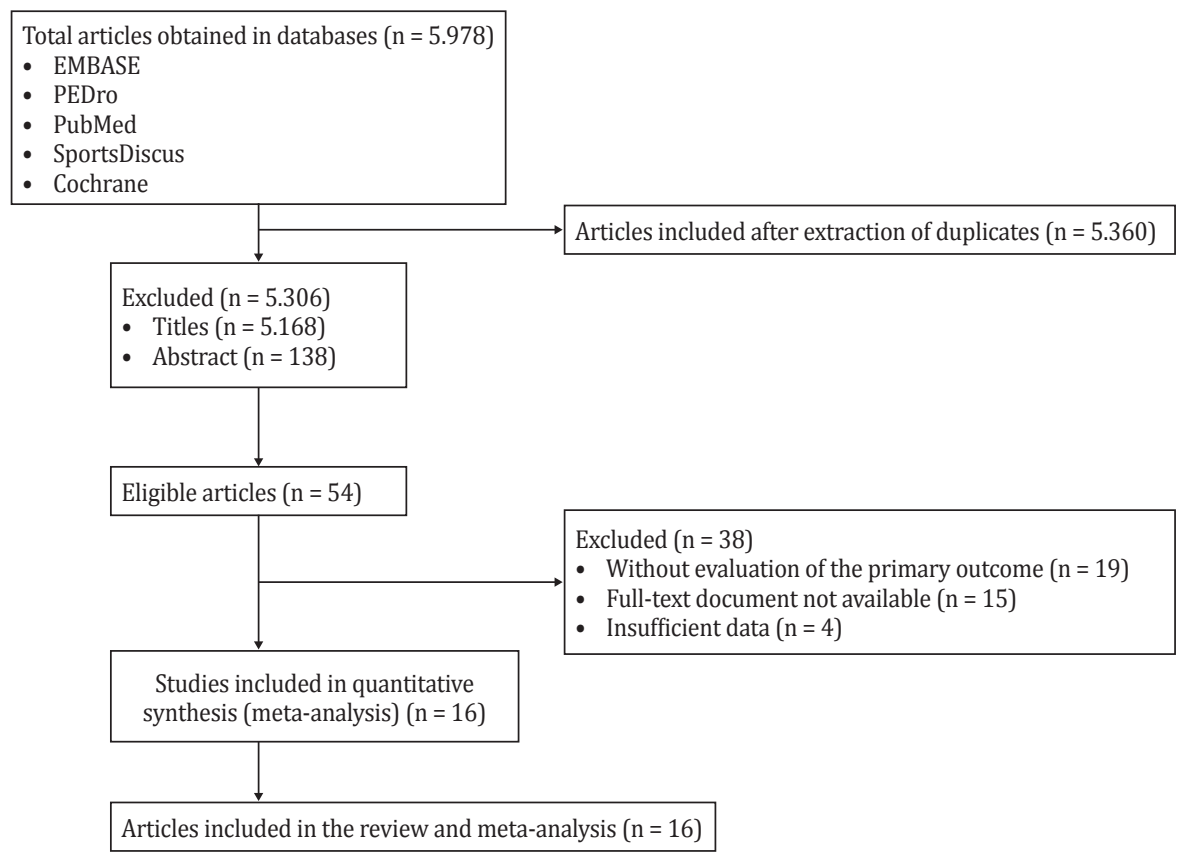

Figure 1 - Selection of studies. 
The studies were conducted in Australia [19, 28], Sweden [24, 27], Denmark [29], Netherlands [21, 30, 31], Nigeria [32], Italy [33], Norway [22, 34, 35], Finland [36], USA [22, 37], and Switzerland [23]. The interventions used varied between eccentric exercise $[19,24,29,31,34]$, warm-up [9, 21, 22, 23, 30, 32, 33, 37 , and neuromuscular training [27, 28, 36].

The 16 studies selected included healthy participants aged between 13 and 39 years, including physically active individuals, junior athletes, professional basketball athletes, and elite and amateur soccer players. Furthermore, for all the studies included, the preventive intervention was compared with a control condition, characterized by routine training, without any strategy for preventive purposes. The characteristics of the studies included are summarized in Table 1.

Table 1 - Characteristics of the studies included

\begin{tabular}{|c|c|c|c|c|}
\hline Study & $\begin{array}{l}\text { Characteristics of } \\
\text { participants }\end{array}$ & Type of intervention & Outcomes analyzed & PEDro Scale \\
\hline Askling et al., 2003 [24] & $\begin{array}{c}\mathrm{N}=30, \text { Male } \\
\text { EG: } 24(2.6) \text { yrs } \\
\text { CG: } 26(3.6) \text { yrs } \\
\text { Soccer players }\end{array}$ & Eccentric exercise & $\begin{array}{l}\text { muscle strength; } \\
\text { index of muscle injury }\end{array}$ & $5 / 10$ \\
\hline Finch et al., 2016 [28] & $\begin{array}{c}\mathrm{N}=1564, \text { Male } \\
18-30 \text { yrs } \\
\text { Soccer players } \\
\text { index of muscle injury }\end{array}$ & Neuromuscular training & & $5 / 10$ \\
\hline Gabbe et al., 2006 [19] & $\begin{array}{c}\mathrm{N}=220 \text {, Male } \\
\text { EG: } 23.4(18.0-35.0) \mathrm{yrs} \\
\text { CG:23.9 (17.4-36.0) yrs } \\
\text { Soccer players }\end{array}$ & Eccentric exercise & index of muscle injury & $4 / 10$ \\
\hline Grooms et al., 2013 [22] & $\begin{array}{c}\mathrm{N}=41, \text { Male } \\
18-25 \text { yrs } \\
\text { Soccer players }\end{array}$ & Warm-up & $\begin{array}{l}\text { index of muscle injury; } \\
\text { time lost to lower extremity } \\
\text { injury }\end{array}$ & \\
\hline Junge et al., 2002 [23] & $\begin{array}{l}\mathrm{N}=194, \text { Male } \\
\text { 14-19 yrs } \\
\text { Soccer players }\end{array}$ & Warm-up & index of muscle injury & \\
\hline Longo et al., 2012 [33] & $\begin{array}{l}\mathrm{N}=121, \text { Male } \\
\text { EG: } 13.5[2.3] \mathrm{yrs} \\
\text { CG: } 15.2[4.6] \mathrm{yrs} \\
\text { Basketball players }\end{array}$ & Warm-up/The11 & $\begin{array}{l}\text { index of muscle injury; } \\
\text { body location, etiology, } \\
\text { mechanism, and severity }\end{array}$ & $8 / 10$ \\
\hline Owoeye et al., 2014 [32] & $\begin{array}{l}\mathrm{N}=416, \text { Male } \\
\text { EG: } 17.8(0.94) \text { yrs } \\
\text { CG: } 17.49(1.10) \text { yrs } \\
\text { Soccer players }\end{array}$ & Warm-up/The11 & $\begin{array}{l}\text { index of muscle injury; } \\
\text { body location, etiology, } \\
\text { mechanism, and severity }\end{array}$ & $6 / 10$ \\
\hline Pasanen et al., 2008 [36] & $\begin{array}{c}\mathrm{N}=457, \text { Female } \\
\text { EG: } 24.2(5.0) \text { yrs } \\
\text { CG: } 23.3(4.8) \text { yrs } \\
\text { Soccer players }\end{array}$ & Neuromuscular training & index of muscle injury & $5 / 10$ \\
\hline Petersen et al.,2011 [29] & $\begin{array}{l}\mathrm{N}=942, \text { Male } \\
\text { EG: } 23.0(4.0) \mathrm{yrs} \\
\text { CG: } 23.5(4.0) \mathrm{yrs} \\
\text { Soccer players }\end{array}$ & Eccentric exercise & index of muscle injury & $6 / 10$ \\
\hline Sebelien et al., 2014 [34] & $\begin{array}{c}\mathrm{N}=142, \text { Male } \\
\text { 18-39 yrs } \\
\text { Soccer Players }\end{array}$ & Eccentric exercise & index of muscle injury & $5 / 10$ \\
\hline Silvers-Granelli et al., 2015 [37] & $\begin{array}{l}\mathrm{N}=1525, \text { Male } \\
20.68(1.46) \mathrm{yrs} \\
20.40(1.66) \mathrm{yrs} \\
\text { Soccer players }\end{array}$ & Warm-up/The11 & index of muscle injury & $6 / 10$ \\
\hline
\end{tabular}


Table 1 - Characteristics of the studies included

\begin{tabular}{|c|c|c|c|c|}
\hline Study & $\begin{array}{c}\text { Characteristics of } \\
\text { participants }\end{array}$ & Type of intervention & Outcomes analyzed & PEDro Scale \\
\hline Soligard et al., 2008 [9] & $\begin{array}{c}\mathrm{N}=1892, \text { Female } \\
\text { 13-17 yrs } \\
\text { Soccer players }\end{array}$ & Warm-up/The11 & index of muscle injury & $5 / 10$ \\
\hline Söderman et al., 2000 [27] & $\begin{array}{c}\mathrm{N}=140, \text { Female } \\
\text { EG: } 20.4(4.6) \mathrm{yrs} \\
\text { CG: } 20.5(5.4) \mathrm{yrs} \\
\text { Soccer players }\end{array}$ & Neuromuscular training & $\begin{array}{l}\text { index of muscle injury; } \\
\text { type of injury suffered }\end{array}$ & $4 / 10$ \\
\hline Steffen et al.,2008 [21] & $\begin{array}{c}\mathrm{N}=2020, \text { Female } \\
\text { To } 17 \text { yrs } \\
\text { Soccer players }\end{array}$ & Warm-up/The11 & index of muscle injury & $7 / 10$ \\
\hline Van Beijsterveldt et al., 2012 [30] & $\begin{array}{c}\mathrm{N}=456, \text { Male } \\
\text { EG: } 24.4(4.1) \mathrm{yrs} \\
\text { CG: } 25.1(4.3) \mathrm{yrs} \\
\text { Soccer players }\end{array}$ & Warm-up /The11 & $\begin{array}{l}\text { index and severity of muscle } \\
\text { injury }\end{array}$ & $5 / 10$ \\
\hline Van der Horst et al, 2015 [31] & $\begin{array}{c}\mathrm{N}=579, \text { Male } \\
24.5(3.8) \text { yrs } \\
\text { Soccer players }\end{array}$ & Eccentric exercise & $\begin{array}{l}\text { Index and severity of muscle } \\
\text { injury }\end{array}$ & $6 / 10$ \\
\hline
\end{tabular}

Note: yrs: years; N: number of participants; CG: control group; EG: experimental group. Data are presented in mean, maximum, minimum, and standard deviation values

Methodological quality of the studies included and risk of bias evaluation

The evaluation of the methodological quality of the studies showed an average of 5.5 points on the PEDro scale. Two studies [21, 33] were considered "high quality", twelve [9, 19, 24, 27-32, 34, 37] were considered "moderate quality", and the other two studies $[22,23]$ were not classified because they are not a randomized clinical trial but a cohort study.
According to GRADE, the overall quality of the evidence was classified as moderate [25].

\section{Interventions}

\section{Eccentric Exercise}

The meta-analysis contained a sample number equivalent to 1,913 individuals and had a favorable effect on the intervention group (RR $=3.49,95 \% \mathrm{CI}$ 2.36, 5.16, $\mathrm{p}<0.00001$ ) (Figure 2).

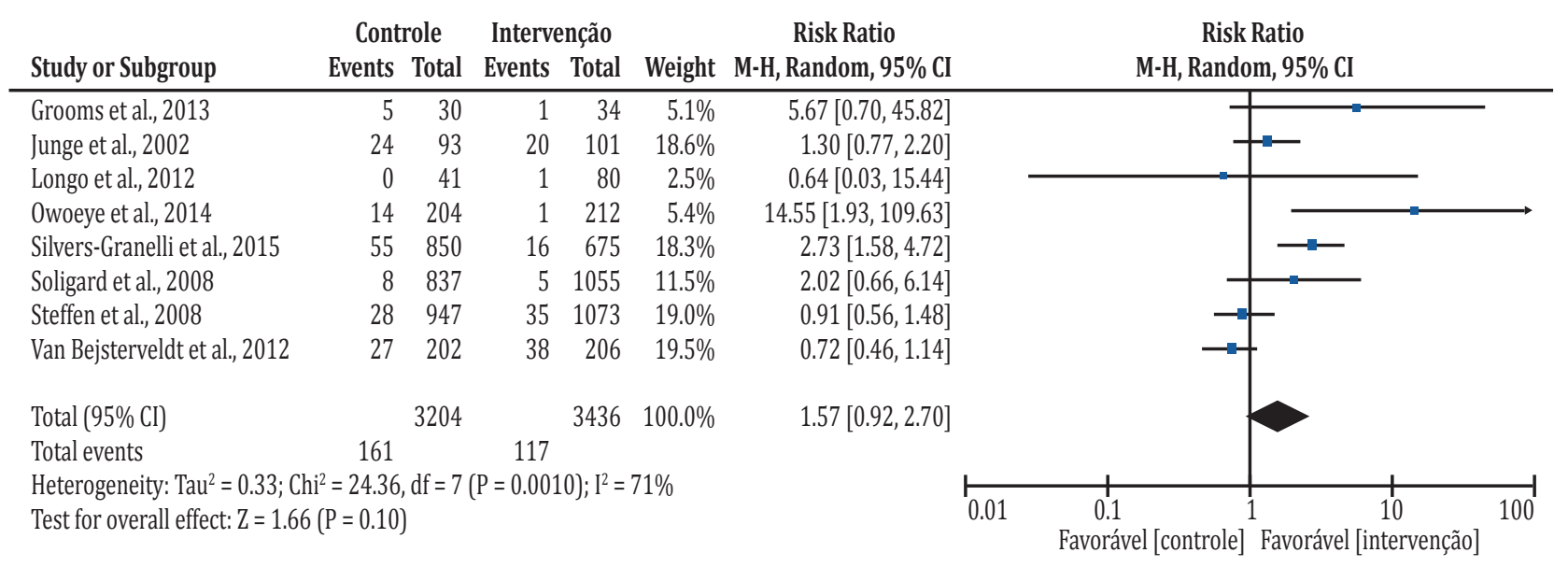

Note: M-H: Mantel-Haenszel; RR: Risk Ratio.

Figure 2 - Forest plot (fixed effect) illustrating the effect of the intervention (eccentric exercise) versus control condition on injury prevention. 
Warm-up

Eight studies included compared the warm-up intervention with routine training (control). The meta-analysis had no effect for any of the groups $(\mathrm{RR}=1.57,95 \% \mathrm{CI} 0.92,2.7, \mathrm{p}=0.10)$, as shown in Figure 3. The final sample consisted of 6,640 individuals.

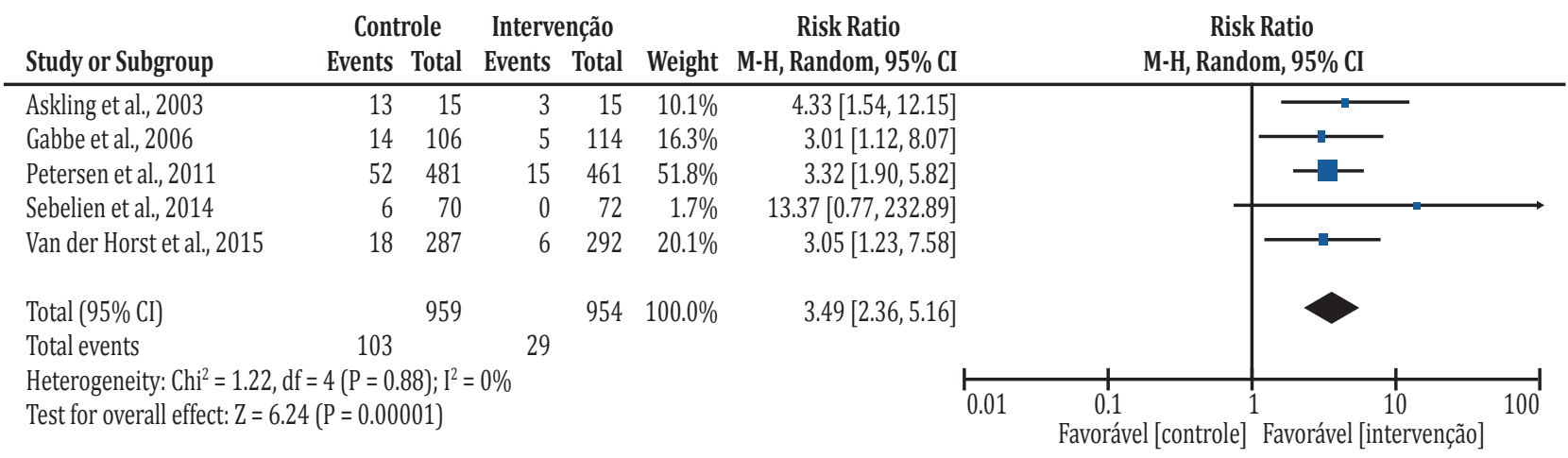

Note: M-H: Mantel-Haenszel; RR: Risk Ratio.

Figure 3 - Forest plot (random effect) illustrating the effect of the intervention (heating) versus control condition on injury prevention.

Neuromuscular Training

The meta-analysis had a favorable effect on the intervention and showed a sample number equivalent to $2.161(\mathrm{RR}=2.73,95 \% \mathrm{CI} 2.03,2.68$, $\mathrm{p}<0.00001)$. These outcomes are observed in Figure 4 .

\begin{tabular}{|c|c|c|c|c|c|c|c|c|c|}
\hline Study or Subgroup & \multicolumn{2}{|c|}{ Controle } & \multicolumn{2}{|c|}{ Intervenção } & Weight & Risk Ratio & \multicolumn{2}{|c|}{$\begin{array}{c}\text { Risk Ratio } \\
\text { M-H, Random, 95\% CI }\end{array}$} & \\
\hline Finch et al., 2016 & 105 & 679 & 53 & 885 & $89.3 \%$ & $2.58[1.88,3.54]$ & & & \\
\hline Pasanen et al., 2008 & 14 & 201 & 5 & 256 & $8.5 \%$ & $3.57[1.31,9.74]$ & & & \\
\hline Söderman et al., 2000 & 7 & 78 & 1 & 62 & $2.2 \%$ & $5.56[0.70,44.03]$ & & & \\
\hline Total $(95 \%$ CI) & & 958 & & 1203 & $100.0 \%$ & $2.73[2.03,3.68]$ & & & \\
\hline Total events & 126 & & 59 & & & & & & \\
\hline Heterogeneity: $\mathrm{Chi}^{2}=$ & $2(\mathrm{P}=0$. & 65); $\mathrm{I}^{2}=$ & $0 \%$ & & & & & & \\
\hline Test for overall effect: & $(\mathrm{P}=0.00$ & 001) & & & & $\overbrace{0.01}$ & 0.1 & 10 & 100 \\
\hline
\end{tabular}

Note: M-H: Mantel-Haenszel; RR: Risk Ratio.

Figure 4 - Forest plot (fixed effect) illustrating the effect of intervention (neuromuscular training) versus control condition on injury prevention.

\section{Discussion}

The findings of this systematic review and meta-analysis showed eccentric exercise and neuromuscular training were effective in preventing lower limb muscle injury when compared with a control group. Regarding warm-up, no significant difference was observed between groups.

The systematic review by Ferreira et al. [38] investigated the effectiveness of different exercise programs (concentric and eccentric strength, Nordic Hamstrings, and "FIFA 11+") in the prevention of hamstring injuries in male soccer players. The outcomes observed were similar to the findings of this study concerning eccentric strength training. This study concluded that, among the protocols investigated, eccentric training was the most effective in reducing the incidence of hamstring injuries when compared with groups with conventional training. In this regard, Opar 
et al. [18] found imbalance of eccentric strength between limbs increases the risk of muscle injury in Australian soccer players.

This datum seems to support the positive preventive outcomes from eccentric training. In this aspect, one believes that the eccentric exercise is responsible for guaranteeing abilities related to levels of strength, resistance, balance, and coordination acting specifically on muscle tissue and ensuring a lower propensity on the incidence of muscle injuries. In this sense, recent studies $[39,40]$ have shown that hamstring muscle injuries occur at the end of the race, during the eccentric phase of the muscle and the deceleration.

Neuromuscular training began to be incorporated into sports practice to reduce the risk of knee and ankle injuries [36]. However, studies have shown the relationship of this training with muscle stretching injuries, as highlighted by Pasanen et al. [36], which verify the effectiveness of training in preventing injuries without direct contact in the lower limbs of female floorball players (Hockey indoor). The result of their clinical trial is similar to the findings of this meta-analysis, highlighting the favorable effect of injury prevention, including the muscle strain in the thigh.

In this way, in the sport field, different modalities include the warm-up in the routine of exercises aimed at preventing injuries and preparing body and mind for the sport practice. However, the literature diverges on the actual effectiveness of warm-up programs in the prevention of injury incidence. The results of this study are indifferent regarding the association between warm-up and prevention of muscle injury in the lower limbs [36, $39,41,42]$, which suggests a lack of relationship between warm-up and a lower incidence of muscle injuries in the lower limb. Thus, this concept could be extrapolated to clinical practice and rethought when the goal is to prevent muscle injuries in the lower limb.

Additionally, these findings provide relevant evidence for clinical and scientific practice on a topic of increasing popularity, use associated with low cost, and accessibility associated with the application of the methods investigated. However, one emphasizes that the findings are related to different populations, as well as protocols, which limits the applicability on variables different from those analyzed.
This study has limitations related to the fact that no restriction was placed regarding the new events or episodes of recurrence, always opting for the total event number of both groups. Observing if participants with or without history of injury composed the sample of the studies is important, since this is one of the main risk factors for this type of injury. Therefore, one suggests new systematic review studies investigate the efficacy of evaluation methods and intensity control, in different populations and variables.

In contrast, strengths are associated with the search strategy used, without sample or time restriction. The PEDro scale was also used to evaluate the methodological quality of the studies included, as well as the GRADE System to evaluate the quality of the evidence and a pre-registration of the study

Thus, one suggests future studies implement investigations on specific sports populations to verify the efficacy of the preventive interventions analyzed in specific sport modalities.

\section{Conclusion}

Evidence from this study suggests neuromuscular training and eccentric exercise have proved to be beneficial in preventing lower limb muscle injury. These findings provide coaches, physiotherapists, and even patients with evidence on specific strategies regarding the prevention of muscle injuries in the body segment investigated.

\section{References}

1. Goode AP, Reiman MP, Harris L, DeLisa L, Kauffman U, Beltramo D, et al. Eccentric training for prevention of hamstring injuries may depend on intervention compliance: a systematic review and meta-analysis. Br J Sports Med. 2015;49(6):349-56.

2. Mueller-Wohlfahrt HW, Haensel L, Mithoefer K, Ekstrand J, English B, McNally S, et al. Terminology and classification of muscle injuries in sport: the Munich consensus statement. J Sports Med. 2013;47(6):342-50.

3. Ekstrand J, Hagglund M, Walden M. Epidemiology of muscle injuries in professional football (soccer). Am J Sports Med. 2011;39(6):1226-32. 
4. Ekstrand J, Waldén M, Hägglund M. Hamstring injuries have increased by $4 \%$ annually in men's professional football, since 2001: a 13-year longitudinal analysis of the UEFA Elite Club injury study. Br J Sports Med. 2016;50(12):731-7.

5. Bizzini M, Dvorak J. FIFA 11+: an effective programme to prevent football injuries in various player groups worldwide: a narrative review. Br J Sports Med. 2015;49(9):577-9.

6. van der Horst N. Preventing hamstring injuries in football through enhanced exercise and RTP strategies. Br J Sports Med. 2018;52(10):684-5.

7. Hoyo M, Pozzo M, Sañudo B, Carrasco L, Gonzalo-Skok O, Domínguez-Cobo S, et al. Effects of a 10-week in-season eccentric-overload training program on muscle-injury prevention and performance in junior elite soccer players. Human Kinetics. 2015;10(1)46-52.

8. Timpka T, Alonso JM, Jacobsson J, Junge A, Branco P, Clarsen B, et al. Injury and illness definitions and data collection procedures for use in epidemiological studies in athletics (track and field): consensus statement. Br J Sports Med. 2014;48(7):483-90.

9. Soligard T, Steffen K, Palmer D, Alonso JM, Bahr R, Lopes AD, et al. A sports injury and illness incidence in the Rio de Janeiro 2016 Olympic Summer Games: a prospective study of 11274 athletes from 207 countries. Br J Sports Med. 2017;51(17):1265-71.

10. Engebretsen L, Soligard T, Steffen K, Alonso JM, Aubry M, Budgett R, et al. Sports injuries and illnesses during the London Summer Olympic Games. Br J Sports Med. 2013;47(7):407-14.

11. Shield AJ, Bourne MN. Hamstring injury prevention practices in elite sport: evidence for eccentric strength vs. lumbo-pelvic training. Sports Med. 2017;48(3):513-24.

12. Timmins RG, Bourne MN, Shield AJ, Williams MD, Lorenzen C, Opar DA. Short biceps femoris fascicles and eccentric knee flexor weakness increase the risk of hamstring injury in elite football (soccer): a prospective cohort study. Br J Sports Med. 2016;50(24):1524-35.
13. Schuermans J, van Tiggelen D, Danneels L, Witvrouw E. Susceptibility to hamstring injuries in soccer: a prospective study using muscle functional magnetic resonance imaging. Am J Sports Med. 2016;44(5):1276-85.

14. van der Horst N, Smits DW, Petersen J, Goedhart EA, Backx FJG. The preventive effect of the Nordic hamstring exercise on hamstring injuries in amateur soccer players: a randomized controlled trial. Am J Sports Med. 2016;43(6):1316-23.

15. Al Attar WSA, Soomro N, Sinclair PJ, Pappas E, Sanders RH. Effect of injury prevention programs that include the nordic hamstring exercise on hamstring injury rates in soccer players: a systematic review and meta-analysis. Sports Med. 2017;47(5):907-16.

16. Räisänen AM, Pasanen K, Krosshaug T, Vasankari T, Kannus P, Heinonen, A, et al. Association between frontal plane knee control and lower extremity injuries: a prospective study on young team sport athletes. BMJ Open Sport Exerc Med. 2018;4(1):e000311.

17. De Ridder R, Witvrouw E, Dolphens M, Roosen P, van Ginckel A. Hip strength as an intrinsic risk factor for lateral ankle sprains in youth soccer players: a 3-season prospective study. Am J Sports Med. 2017;45(2):410-6.

18. Opar DA, Williams MD, Timmins RG, Hickey J, Duhig SJ, Shield AJ. Eccentric hamstring strength and hamstring injury risk in Australian footballers. Med Sci Sports Exerc. 2015;47(4):857-65.

19. Gabbe BJ, Bennell KL, Finch CF, Wajswelner H, Orchard JW. Predictors of hamstring injury at the elite level of Australian football. Scand J Med Sci Sports. 2006;16(1):7-13.

20. Hägglund M, Waldén $M$, Ekstrand J. Risk factors for lower extremity muscle injury in professional soccer: the UEFA injury study. Am J Sports Med. 2013;41(2):327-35.

21. Steffen K, Myklebust G, Olsen O. E, Holme I, Bahr R. Preventing injuries in female youth football: a clusterrandomized controlled trial. Scand J Med Sci Sports. 2008;18(5):605-14. 
22. Grooms DR, Palmer T, Onate J, Myer G, Grindstaff T. Soccer-specific warm-up and lower extremity injury rates in Collegiate Male Soccer Players. J Athl Train. 2013;48(6):782-9.

23. Junge A, Rosch D, Peterson L, Graf-Baumann T, Dvorak J. Prevention of soccer injuries: a prospective intervention study in youth amateur players. Am J Sports Med. 2002;30(5):652-9.

24. Askling C, Karlsson J, Thorstensson A. Hamstring injury occurrence in elite soccer players after preseason strength training with eccentric overload. Scand J Med Sci Sports. 2003;13(4):244-50.

25. Machado AF, Micheletti JK, Lopes JSS, Vanderlei FM, Leal ECP Jr, Netto J Jr, et al. Phototherapy on management of creatine kinase activity in general versus localized exercise: systematic review and meta-analysis. Clin J Sport Med. 2018. [Epub ahead of print].

26. Lopes JSS, Machado AF, Micheletti JK, Almeida AC, Cavina AP, Pastre CM. Effects of training with elastic resistance versus conventional resistance on muscular strength: a systematic review and meta-analysis. SAGE Open Med. 2019;7:2050312119831116.

27. Söderman $K$, Werner $S$, Pietilä $T$, Engström B, Alfredson $\mathrm{H}$. Balance board training: prevention of traumatic injuries of the lower extremities in female soccer players? A prospective randomized intervention study. Knee Surg Sports Traumatol Arthrosc. 2000;8(6):356-63.

28. Finch CF, Twomey DM, Fortington LV, Doyle TLA, Elliott BC, Akram M, et al. Preventing Australian football injuries with a targeted neuromuscular control exercise programme: comparative injury rates from a training intervention delivered in a clustered randomised controlled trial. Inj Prev. 2016;22(2):123-8.

29. Petersen J, Thorborg K, Nielsen MB, Budtz-Jørgensen E, Hölmich P. Preventive effect of eccentric training on acute hamstring injuries in men's soccer: a clusterrandomized controlled trial. Am J Sports Med. 2011;39(11):2296-303.
30. van Beijsterveldt AMC, van der Port IGL, Krist MR, Schmikli SL, Stubbe JH, Frederiks JE, et al. Effectiveness of an injury prevention programme for adult male amateur soccer players: a cluster-randomised controlled trial. Br J Sports Med. 2012;46(16):1114-8.

31. van der Horst N, Smits DW, Petersen J, Goedhart EA, Backx FJG. The preventive effect of the Nordic hamstring exercise on hamstring injuries in amateur soccer players: a randomized controlled trial. Am J Sports Med. 2015;43(6):1316-23.

32. Owoeye OB, Akinbo SR, Tella BA, Olawale OA. Efficacy of the FIFA 11+ warm-up programme in male youth football: a cluster randomised controlled trial. J Sports Sci Med. 2014;13(2):321-8.

33. Longo UG, Loppini M, Berton A, Marinozzi A, Maffulli N, Denaro V. The FIFA 11+ program is effective in preventing injuries in elite male basketball players: a cluster randomized controlled trial. Am J Sports Med. 2012;40(5):996-1005.

34. Sebelien C, Stiller CH, Maher SF, Xianggui Q. Effects of implementing Nordic hamstring exercises for semiprofessional soccer players in Akershus, Norway. Orthopaedic Practice. 2014;26(2):90-7.

35. Soligard T, Myklebust G, Steffen K, Holme I, Silvers H, Bizzini M, et al. Comprehensive warm-up programme to prevent injuries in young female footballers: cluster randomized controlled trial. BMJ. 2008;337:a2469.

36. Pasanen K, Parkkari J, Pasanen M, Hilloskorpi H, Makinen T, Jarvinen $\mathrm{M}$, et al. Neuromuscular training and the risk of leg injuries in female floorball players: cluster randomised controlled study. BMJ. 2008;337:a295.

37. Silvers-Granelli H, Mandelbaum B, Adeniji O, Insler S, Bizzini M, Pohlig R, et al. Efficacy of the FIFA 11+ injury prevention program in the Collegiate Male Soccer Player. Am J Sports Med. 2015;43(11):2628-37.

38. Ferreira AC, Marujo A, Folgado H, Gutierres PF, Fernandes J. Programas de exercício na prevenção de lesões em jogadores de futebol: Uma revisão sistemática. Rev Bras Med Esporte. 2015;21(3):236-41. 
39. Lempainen L, Banke IJ, Johansson K, Brucker PU, Sarimo J, Orava S, et al. Clinical principles in the management of hamstring injuries. Knee Surg Sports Traumatol Arthrosc. 2015;23(8):2449-56.

40. Askling CM, Kolouris G, Saartok T, Werner S, Best TM. Total proximal hamstring ruptures: clinical and MRI aspects including guidelines for postoperative rehabilitation. Knee Surg Sports Traumatol Arthrosc. 2013;21(3):515-33.

41. Beijsterveldt AMC, van der Port IGL, Vereijken AJ, Backx FJ. Risk factors for hamstrings injuries in male soccer players: a systematic review of prospective studies. Scand J Med Sci Sports. 2013;23(3):253-62.
42. Goode AP, Reiman MP, Harris L, DeLisa L, Kauffman U, Beltramo D, et al. Eccentric training for prevention of hamstring injuries may depend on intervention compliance: a systematic review and meta-analysis. Br J Sports Med. 2015;49(6):349-56.

Received on 10/31/2018

Recebido em 31/10/2018

Recibido en 31/10/2018

Approved on 04/01/2019

Aprovado em 01/04/2019

Aprobado en 01/04/2019 